\section{Biomass accumulation and carbon stock in different agroforestry systems prevalent in the Himalayan foothills, India}

\author{
Amit Kumar ${ }^{1, *}$, Salil Tewari ${ }^{2}$, Hukum Singh ${ }^{1}$, \\ Parmanand Kumar ${ }^{1}$, Narendra Kumar ${ }^{1}$, \\ Sarita Bisht ${ }^{1}$, Suruchi Devi ${ }^{1}$, Nidhi ${ }^{1}$ and \\ Rajesh Kaushal ${ }^{3}$ \\ ${ }^{1}$ Forest Research Institute, Dehradun 248 006, India \\ ${ }^{2}$ G. B. Pant University of Agriculture and Technology, \\ Pantnagar 263 145, India \\ ${ }^{3}$ ICAR-Indian Institute of Soil and Water Conservation, \\ Dehradun 248 001, India
}

Agroforestry has great potential for carbon (C) sequestration among different land uses of the Himalayan region, India. However, our knowledge of $C$ sequestration in particular, agroforestry system around the world is poor. Therefore, we conducted a study to understand biomass accumulation and carbon allocation in different components of the agroforestry system. The highest stem biomass was recorded in Eucalyptus tereticornis $\left(69.43 \pm 0.90 \mathrm{Mg} \mathrm{ha}^{-1}\right)$, branch biomass in Populus deltoids (5.04 $\left.\pm 0.35 \mathrm{Mg} \mathrm{ha}^{-1}\right)$, leaf biomass also in $P$. deltoids $\left(2.21 \pm 0.12 \mathrm{Mg} \mathrm{ha}^{-1}\right)$, and root biomass in Albizia procera $\left(14.01 \pm 0.44 \mathrm{Mg} \mathrm{ha}^{-1}\right)$. The highest $(81.01 \%) C$ allocation was recorded in the stem of Toona ciliate, branch of $P$. deltoids $(5.73 \%)$, leaves of E. tereticornis $(2.93 \%)$ and root of Anthocephalus cadamba (16.83\%). The highest $\mathrm{CO}_{2}$ mitigation (160.5 \pm $\left.2.55 \mathrm{Mg} \mathrm{CO}_{2} \mathrm{ha}^{-1}\right)$ and $\mathrm{C}$ sequestration (45.33 \pm $0.60 \mathrm{Mg} \mathrm{ha}^{-1}$ ) were recorded in $E$. tereticornis. The highest wheat crop biomass $\left(11.85 \pm 0.23 \mathrm{Mg} \mathrm{ha}^{-1}\right)$ and C stock $\left(3.59 \pm 0.05 \mathrm{Mg} \mathrm{ha}^{-1}\right)$ were recorded in $P$. deltiodes. However, soil carbon stock was recorded in $E$. tereticornis $\left(37.5 \pm 3.52 \mathrm{Mg} \mathrm{ha}^{-1}\right)$. Thus, trees on farmlands with crops are suitable for biomass production and $C$ allocation in different components under changing climatic scenarios.

Keywords: Agroforestry system, biomass, carbon stock, carbon dioxide mitigation, climate change.

THE carbon stored in soil and biomass under agroforestry is substantially greater than the sole cropping system. In India, the average carbon sequestration potential in agroforestry has been estimated to be 25 tonnes per hectare over $96 \mathrm{~m} \mathrm{ha}^{-1}$ area $^{1}$. However, these estimates are mostly derived from biomass productivity and not from the soil stocks. Generally, carbon may be sequestered in mineral soil after conversion from intensively cultivated agricultural fields to more comprehensive land uses such as forested ecosystems ${ }^{2}$. Biomass stock and its storage rate play an important role in fulfiling the rising demand for

\footnotetext{
*For correspondence. (e-mail: amitudu@gmail.com)
}

tree products and in mitigating the climate change problem. Therefore, it is imperative to assess biomass accumulation in different agroforestry systems. Promoting agroforestry is one of the options to resolve land use and $\mathrm{CO}_{2}$-induced global warming issues ${ }^{3}$. Any type of agroforestry system can yield carbon credits from the inclusion of trees in farmlands, and the overall carbon stock of the ecosystem would increase in the trees and soil.

Wheat is one of the agroforestry crops grown in the foothills of the Indian Himalaya. It is intercropped with different tree species during rabi season and in this intercropping, both trees and crops compete for available light and soil resources (water, nutrients, etc. $)^{4}$.

There is little information on the accumulation of biomass and carbon stocks in various agroforestry systems. Current information is only available for tree species and not their various components and the understorey crops. Keeping this in view, we conducted the present study to evaluate biomass accumulation and carbon stock under different components of agroforestry which are prevalent in the Himalayan foothills of India. The study was undertaken with the following objectives: (i) to quantify the biomass of different components of the agroforestry system, and (ii) to measure carbon stock in the biomass as well as in soils of different agroforestry systems.

This study was conducted on agroforestry systems practiced by farmers in Dhanauri range of Haridwar district, Uttarakhand, India. Dhanauri is situated at $29.94 \mathrm{~N}$ lat. and $77.95 \mathrm{E}$ long. with an altitude $249.8 \mathrm{~m}$ amsl in the foothills of the Indian Himalaya. It falls in the subhumid and sub-tropical climatic zone of the country.

In this study, we selected eight different agroforestry systems. Wheat (Triticum aestivum) is the main agricultural crop that is intercropped with trees in this area. We estimated the above- and below-ground biomass of these eight agroforestry systems, i.e. Populus deltoids, Toona ciliata, Eucalyptus tereticornis, Albizia procera, Melia azedarach, Terminalia bellirica, Anthocephalus cadamba and Sapindus mukorosi. These agroforestry tree species were planted at $4 \times 4 \mathrm{~m}$ spacing in 2007 . Earlier, in all the agroforestry systems, farmers had used wheat, sugarcane, soybean, potato, jowar and turmeric as intercrops. However, in the present study, we considered only wheat crop that was intercropped in all agroforestry systems, since the farmers were now growing only this crop.

The biomass of each component (stem, branch and leaf) of the trees was calculated by destructive sampling. All the tree species were replicated thrice (three trees were harvested for each tree species). After felling, above-ground parts, viz. stem, branch and leaf were separated. The stem was then cross-cut into logs of appropriate length depending upon its general form. The fresh weight of each log was taken in the field for each sample tree with the help of heavy weight spring balance. Three cross-sectional discs representing the top, middle and bottom portions of the tree stem were taken from each 


\section{RESEARCH COMMUNICATIONS}

Table 1. Biomass of different agroforestry components $\left(\mathrm{Mg} \mathrm{ha}^{-1}\right)$

\begin{tabular}{|c|c|c|c|c|c|c|c|c|}
\hline \multirow{2}{*}{$\begin{array}{l}\text { Agroforestry } \\
\text { system }\end{array}$} & \multicolumn{5}{|c|}{ Tree species } & \multicolumn{3}{|c|}{ Wheat crop } \\
\hline & Stem & Branch & Leaf & Root & Total & SLG & Root & Total \\
\hline $\begin{array}{l}\text { Populus } \\
\text { deltoides }\end{array}$ & $66.8 \pm 0.45^{\mathrm{a}}$ & $5.04 \pm 0.35^{\mathrm{a}}$ & $2.21 \pm 0.12^{\mathrm{b}}$ & $11.03 \pm 0.28^{\mathrm{bc}}$ & $85.0 \pm 1.94^{\mathrm{b}}$ & $9.81 \pm 0.17^{\mathrm{a}}$ & $2.04 \pm 0.16^{\mathrm{a}}$ & $11.85 \pm 0.23^{\mathrm{a}}$ \\
\hline Toona ciliata & $62.06 \pm 1.26^{\mathrm{b}}$ & $3.66 \pm 0.63^{b}$ & $1.94 \pm 0.10^{\mathrm{b}}$ & $9.39 \pm 0.31^{\mathrm{c}}$ & $76.45 \pm 1.17^{\mathrm{c}}$ & $8.56 \pm 0.17^{\mathrm{cd}}$ & $1.23 \pm 0.02^{\mathrm{c}}$ & $9.79 \pm 0.15^{\mathrm{d}}$ \\
\hline $\begin{array}{l}\text { Eucalyptus } \\
\quad \text { tereticornis }\end{array}$ & $69.43 \pm 0.90^{\mathrm{a}}$ & $3.63 \pm 0.36^{\mathrm{b}}$ & $2.85 \pm 0.08^{\mathrm{a}}$ & $11.22 \pm 0.02^{\mathrm{a}}$ & $89.43 \pm 0.28^{\mathrm{a}}$ & $9.18 \pm 0.13^{\mathrm{b}}$ & $1.66 \pm 0.11^{\mathrm{b}}$ & $10.84 \pm 0.22^{b}$ \\
\hline $\begin{array}{l}\text { Albizia } \\
\quad \text { procera }\end{array}$ & $53.42 \pm 1.31^{\mathrm{cd}}$ & $3.34 \pm 0.22^{b c}$ & $1.86 \pm 0.17^{\mathrm{bc}}$ & $14.01 \pm 0.44^{\mathrm{c}}$ & $68.18 \pm 0.85^{d}$ & $8.26 \pm 0.12^{\mathrm{d}}$ & $1.35 \pm 0.03^{\mathrm{c}}$ & $9.61 \pm 0.11^{\mathrm{d}}$ \\
\hline $\begin{array}{l}\text { Melia } \\
\quad \text { azedarach }\end{array}$ & $50.13 \pm 0.94^{\mathrm{de}}$ & $3.07 \pm 0.28 b^{c}$ & $1.45 \pm 0.10^{\mathrm{cd}}$ & $9.68 \pm 0.33^{\mathrm{c}}$ & $64.94 \pm 0.72^{\mathrm{ef}}$ & $8.37 \pm 0.14^{\mathrm{d}}$ & $1.22 \pm 0.02^{\mathrm{c}}$ & $9.59 \pm 0.14^{\mathrm{d}}$ \\
\hline $\begin{array}{c}\text { Terminalia } \\
\text { bellirica }\end{array}$ & $48.2 \pm 0.40^{\mathrm{e}}$ & $2.41 \pm 0.56^{\mathrm{c}}$ & $1.29 \pm 0.17^{\mathrm{d}}$ & $9.98 \pm 0.06^{\mathrm{c}}$ & $62.07 \pm 0.81^{\mathrm{f}}$ & $9.04 \pm 0.09^{b}$ & $1.42 \pm 0.02^{\mathrm{c}}$ & $10.46 \pm 0.11^{\mathrm{bc}}$ \\
\hline $\begin{array}{c}\text { Anthocephalus } \\
\text { cadamba }\end{array}$ & $55.68 \pm 0.26^{\mathrm{c}}$ & $4.07 \pm 0.28^{\mathrm{ab}}$ & $1.89 \pm 0.15^{\mathrm{b}}$ & $12.53 \pm 0.76^{\mathrm{ab}}$ & $74.0 \pm 0.40^{\mathrm{d}}$ & $8.50 \pm 0.12^{\text {cd }}$ & $1.26 \pm 0.03^{\mathrm{c}}$ & $9.76 \pm 0.13^{\mathrm{d}}$ \\
\hline $\begin{array}{l}\text { Sapindus } \\
\quad \text { mukorosi }\end{array}$ & $52.25 \pm 0.08^{\mathrm{cd}}$ & $3.0 \pm 0.31^{\mathrm{bc}}$ & $1.15 \pm 0.09^{\mathrm{d}}$ & $9.58 \pm 1.14^{\mathrm{c}}$ & $67.37 \pm 1.19^{\mathrm{e}}$ & $8.92 \pm 0.16^{b c}$ & $1.41 \pm 0.02^{\mathrm{c}}$ & $10.33 \pm 0.17^{\mathrm{c}}$ \\
\hline
\end{tabular}

SLG, Stem, leaves and grain. Different letters indicate significant differences $(P<0.05)$ between species. Data with the same letters in the superscript do not differ significantly.

tree to determine moisture content. The same process was also followed for branch and leaf to determine biomass and moisture. Using a JCB machine, the roots of each tree species were dugout to determine the below-ground biomass. All the main roots and fine roots were collected and weighed using a weighing machine to obtain the fresh weight of roots. A known quantity of samples was oven-dried to obtain the biomass of roots. The above- and below-ground biomass of wheat crops was determined by laying out three quadrats $(1 \times 1 \mathrm{~m}$ size $)$ in each agroforestry system.

Carbon concentration in all components of each tree species was determined by combustion method ${ }^{5}$.

Biomass of different tree components and their carbon concentration were multiplied to estimate carbon stock in each component ${ }^{6}$. Carbon dioxide $\left(\mathrm{CO}_{2}\right)$ mitigation by different agroforestry systems was estimated by multiplying the values of carbon stock by a factor of 3.66 (ref. 7). Total carbon sequestration $\left(\mathrm{Mg} \mathrm{ha}^{-1}\right)$ in woody component was estimated by adding long-lived carbon storage in wood products and the carbon storage due to substitution biomass for $\mathrm{coal}^{8}$. The carbon stock in the soil was computed using the formula given by Brown ${ }^{9}$ as follows

Carbon stock $(\mathrm{t} / \mathrm{ha})=\left(\right.$ Soil bulk density $\left(\mathrm{g} / \mathrm{cm}^{3}\right) \times$ Soil depth $(30 \mathrm{~cm}) \times$ soil organic carbon $(\%)) \times 100$.

Data of all parameters were analysed by ANOVA (analysis of variance) following RBD (randomized block design) using $\mathrm{R}$ statistical software. Means were tested using Duncan's test at a significance level of $P \leq 0.005$.

Comparing the biomass contribution of different tree species in agroforestry systems, we found that the contribution of trees to total biomass significantly $(P \leq 0.05)$ varied between $62.06 \pm 1.26$ and $69.43 \pm 0.90 \mathrm{Mg} \mathrm{ha}^{-1}$ in
T. bellirica and E. tereticornis (Table 1). Significantly $(P \leq 0.05)$ highest stem and leaf biomass was recorded in E. tereticornis $\left(69.43 \pm 0.90\right.$ and $2.85 \pm 0.08 \mathrm{Mg} \mathrm{ha}^{-1}$ respectively). The contribution of other species to biomass production (stem, branch, leaf and root) followed the same trend in terms of per cent contribution. The lowest stem and branch biomass was recorded in $T$. bellirica (48.2 \pm 0.40 and $2.41 \pm 0.56 \mathrm{Mg} \mathrm{ha}^{-1}$ respectively). However, lowest $\left(9.39 \pm 0.31 \mathrm{Mg} \mathrm{ha}^{-1}\right)$ root biomass was recorded in $T$. ciliate. Among the different tree components, the highest accumulation of biomass was recorded in stem followed by root, branch and leaf (Figure 1). The highest $(80.54 \%)$ biomass accumulation was recorded in the stem of $T$. ciliate followed by $S$. mukorosi $(79.50 \%)$, P. deltoids (78.52\%), M. azedarach (77.92\%), T. bellirica (77.90\%), A. procera $(77.40 \%)$ and E. tereticornis $(77.13 \%)$. The highest branch biomass accumulation was recorded in P. deltoids (5.92\%), A. cadamba (5.49\%), $M$. azedarach (4.77\%), T. ciliate (4.75\%), S. mukorosi $(4.48 \%)$ and E. tereticornis $(4.03 \%)$. The highest accumulated leaf biomass was recorded in E. tereticornis $(3.27 \%)$, A. procera $(2.69 \%), P$. deltoids $(2.60 \%)$ and $A$. cadamba $(2.55 \%)$. Higher root biomass accumulation was recorded in $A$. cadamba $(16.89 \%)$, T. bellirica $(16.12 \%)$, E. tereticornis $(15.56 \%)$, A. procera $(15.07 \%)$ and $M$. azedarach $(15.05 \%)$.

$\mathrm{CO}_{2}$ mitigation followed the same trend as carbon stock (Table 2). However, total $\mathrm{CO}_{2}$ mitigation was recorded significantly $(P \leq 0.05)$ higher in E. tereticornis $\left(160.50 \pm 2.55 \mathrm{MgCO}_{2} \mathrm{ha}^{-1}\right), P$. deltoids (151.27 \pm 1.79 $\left.\mathrm{MgCO}_{2} \mathrm{ha}^{-1}\right), T$. ciliate $\left(137.38 \pm 2.70 \mathrm{MgCO}_{2} \mathrm{ha}^{-1}\right), A$. cadamba $\quad\left(130.65 \pm 1.95 \mathrm{MgCO}_{2} \mathrm{ha}^{-1}\right), \quad A$. procera $\left(121.06 \pm 2.49 \mathrm{MgCO}_{2} \mathrm{ha}^{-1}\right)$, S. mukorosi $(117.85 \pm 0.88$ $\left.\mathrm{MgCO}_{2} \mathrm{ha}^{-1}\right)$ and $M$. azedarach $\left(115.20 \pm 2.74 \mathrm{MgCO}_{2}\right.$ $\left.\mathrm{ha}^{-1}\right)$ than T. bellirica $\left(109.77 \pm 1.88 \mathrm{MgCO}_{2} \mathrm{ha}^{-1}\right)$. 


\section{RESEARCH COMMUNICATIONS}

Table 2. Carbon dioxide mitigation $\left(\mathrm{Mg} \mathrm{CO}_{2} \mathrm{ha}^{-1}\right)$ through different agroforestry tree components

\begin{tabular}{|c|c|c|c|c|c|}
\hline Agroforestry tree species & Stem & Branch & Leaf & Root & Total \\
\hline P. deltoides & $120.05 \pm 2.11^{\mathrm{a}}$ & $8.67 \pm 0.63^{\mathrm{a}}$ & $3.50 \pm 0.18^{\mathrm{b}}$ & $19.05 \pm 0.58^{\mathrm{bc}}$ & $151.27 \pm 1.79^{b}$ \\
\hline T. ciliata & $111.28 \pm 2.29^{\mathrm{b}}$ & $6.32 \pm 1.14^{\mathrm{b}}$ & $3.05 \pm 0.13^{\mathrm{b}}$ & $16.73 \pm 0.93^{c}$ & $137.38 \pm 2.70^{c}$ \\
\hline A. procera & $94.09 \pm 2.27^{\mathrm{d}}$ & $5.71 \pm 0.32^{\mathrm{bc}}$ & $2.92 \pm 0.21^{\mathrm{b}}$ & $18.34 \pm 0.62^{\mathrm{c}}$ & $121.06 \pm 2.49^{\mathrm{e}}$ \\
\hline M. azedarach & $90.64 \pm 1.72^{\mathrm{de}}$ & $5.32 \pm 0.57^{\mathrm{bc}}$ & $2.25 \pm 0.12^{\mathrm{c}}$ & $16.98 \pm 0.48^{\mathrm{c}}$ & $115.20 \pm 2.74^{\mathrm{ef}}$ \\
\hline S. mukorosi & $93.79 \pm 1.20^{\mathrm{cd}}$ & $5.19 \pm 0.52^{\mathrm{bc}}$ & $1.80 \pm 0.13^{\mathrm{c}}$ & $17.07 \pm 2.26^{\mathrm{c}}$ & $117.85 \pm 0.88^{\mathrm{e}}$ \\
\hline
\end{tabular}

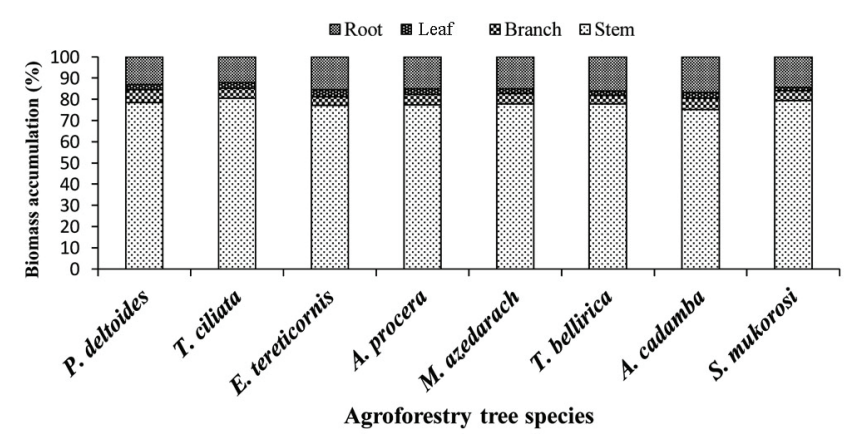

Figure 1. Biomass accumulation in different components of agroforestry tree species.

The highest carbon sequestration was recorded in $E$. tereticornis $\left(31.84 \% ; 45.33 \pm 0.60 \mathrm{Mg} \mathrm{ha}^{-1}\right), P$. deltoids $\left(29.52 \% ; 43.84 \pm 0.93 \mathrm{Mg} \mathrm{ha}^{-1}\right), T$. ciliate $(23.30 \% ; 40.29 \pm$ $\left.1.12 \mathrm{Mg} \mathrm{ha}^{-1}\right)$, A. cadamba $\left(15.48 \% ; 36.56 \pm 0.68 \mathrm{Mg} \mathrm{ha}^{-1}\right)$, A. procera $\left(11.25 \% ; 34.82 \pm 0.60 \mathrm{Mg} \mathrm{ha}^{-1}\right)$, S. mukorosi $\left(9.34 \% ; \quad 34.08 \pm 0.47 \mathrm{Mg} \mathrm{ha}^{-1}\right)$ and $M$. azedarach $\left(4.87 \% ; 32.48 \pm 0.72 \mathrm{Mg} \mathrm{ha}^{-1}\right)$ than T. bellirica $(30.90 \pm$ $0.52 \mathrm{Mg} \mathrm{ha}^{-1}$; Figure 2).

Comparison among different agroforestry systems showed that above-ground wheat biomass significantly $(P \leq 0.05)$ ranged from $8.26 \pm 0.12$ (A. procera) to $9.81 \pm 0.17 \mathrm{Mg} \mathrm{ha}^{-1}(P$. deltiodes $)$ (Table 1). E. tereticornis $\quad\left(9.18 \pm 0.13 \mathrm{Mg} \mathrm{ha}^{-1}\right)$ also showed significant $(P \leq 0.05)$ effect with $A$. procera $\left(8.26 \pm 0.12 \mathrm{Mg} \mathrm{ha}^{-1}\right)$. However, below-ground wheat biomass significantly $(P \leq 0.05)$ ranged from $1.22 \pm 0.02$ (M. azedarach) to $2.04 \pm 0.5 \mathrm{Mg} \mathrm{ha}^{-1}$ (P. deltiodes) (Table 1).

Above-ground $\mathrm{C}$ stock of wheat was recorded significantly $(P \leq 0.05)$ higher under $T$. bellirica $(3.17 \pm$ $\left.0.09 \mathrm{Mg} \mathrm{ha}^{-1}\right)$ followed by $P$. deltoids $(2.96 \pm$ $\left.0.06 \mathrm{Mg} \mathrm{ha}^{-1}\right), \quad S$. mukorosi $\left(2.95 \pm 0.03 \mathrm{Mg} \mathrm{ha}^{-1}\right), \quad M$. azedarach $\quad\left(2.85 \pm 0.04 \mathrm{Mg} \mathrm{ha}^{-1}\right), \quad$ E. tereticornis $\left(2.83 \pm 0.08 \mathrm{Mg} \mathrm{ha}^{-1}\right)$, A. cadamba $\left(2.74 \pm 0.09 \mathrm{Mg} \mathrm{ha}^{-1}\right)$, T. ciliate $\left(2.71 \pm 0.10 \mathrm{Mg} \mathrm{ha}^{-1}\right)$ and $A$. procera $(2.65 \pm$ $\left.0.02 \mathrm{Mg} \mathrm{ha}^{-1}\right)$. However, the highest below-ground $\mathrm{C}$ stock was recorded in P. deltoids $\left(2.04 \pm 0.05 \mathrm{Mg} \mathrm{ha}^{-1}\right)$, followed by E. tereticornis $\left(1.66 \pm 0.04 \mathrm{Mg} \mathrm{ha}^{-1}\right), T$. bellirica $\quad\left(1.42 \pm 0.02 \mathrm{Mg} \mathrm{ha}^{-1}\right), \quad S . \quad$ mukorosi $(1.41 \pm$ $\left.0.02 \mathrm{Mg} \mathrm{ha}^{-1}\right)$, A. procera $\left(1.35 \pm 0.02 \mathrm{Mg} \mathrm{ha}^{-1}\right)$, A. cadamba $\quad\left(1.26 \pm 0.02 \mathrm{Mg} \mathrm{ha}^{-1}\right), \quad$ T. ciliate $(1.23 \pm$
$0.02 \mathrm{Mg} \mathrm{ha}^{-1}$ ) and M. azedarach $\left(1.22 \pm 0.02 \mathrm{Mg} \mathrm{ha}^{-1}\right)$ (Table 3). Total $\mathrm{C}$ stock in wheat crop was recorded highest in T. bellirica (15.89\%), P. deltoids (14.48\%), $S$. mukorosi (9.44\%), E. tereticornis $(8.08 \%)$, A. cadamba $(2.23 \%)$ and $T$. ciliate $(1.29 \%)$ than $A$. procera (Table 4$)$.

Among agroforestry systems significant $(P \leq 0.05)$ maximum soil carbon density was recorded in E. tereticornis $\left(37.50 \pm 3.52 \mathrm{Mg} \mathrm{ha}^{-1}\right)$, followed by $P$. deltoids $\left(30.75 \pm 2.06 \mathrm{Mg} \mathrm{ha}^{-1}\right), \quad M . \quad$ azedarach $\quad(28.46 \pm$ $\left.1.06 \mathrm{Mg} \mathrm{ha}^{-1}\right)$ and $T$. bellirica $\left(26.56 \pm 0.75 \mathrm{Mg} \mathrm{ha}^{-1}\right)$ (Table 4). Soil carbon density in $A$. procera was at par with $T$. bellirica and lowest in A. cadamba (24.41 \pm 1.26 $\mathrm{Mg} \mathrm{ha}^{-1}$ ).

Production of biomass in different tree components, i.e. stem, branch, leaf, and root depends on various factors such as site quality, growth habit, age, management practices and, most importantly, on how the species interact with the local climate, with the crops and sourcesink relationship with trees ${ }^{10}$. The contribution of stem, branch, root and litter biomass was found to be greatly influenced by vegetation type, which influences not only the overall production of biomass but also its partitioning into different components. Our findings are consistent with previous studies, indicating that biomass in agroforestry has significantly increased with morphological variation $^{11}$

In the present study, the pattern of biomass allocation reflected that more biomass was allocated to aboveground components like stem, branch and foliage compared to below-ground parts, which resulted in a higher shoot/root ratio. Tree stem biomass is a function of the volume of stem density; so the volume and biomass estimation is influenced by diameter at breast height $(\mathrm{DBH})$ and height of the stem ${ }^{12}$. Density and spacing of tree species also affect biomass allocation and contribute a greater percentage of total biomass production due to lesser competition and better availability of nutrients ${ }^{13}$. In $P$. deltoids, root distribution pattern decreased with increased radial distance from the tree base at all soil depths. In this species, there was a marginal extension of stump root and lateral root beyond $1.5 \mathrm{~m}^{3}$ zone of soil volume $^{14}$. Several earlier studies have revealed that most of the root density declines with vertical depth and distance from the tree ${ }^{15}$. The accumulation of more roots in 
Table 3. Carbon stock in different agroforestry components $\left(\mathrm{Mg} \mathrm{ha}^{-1}\right)$

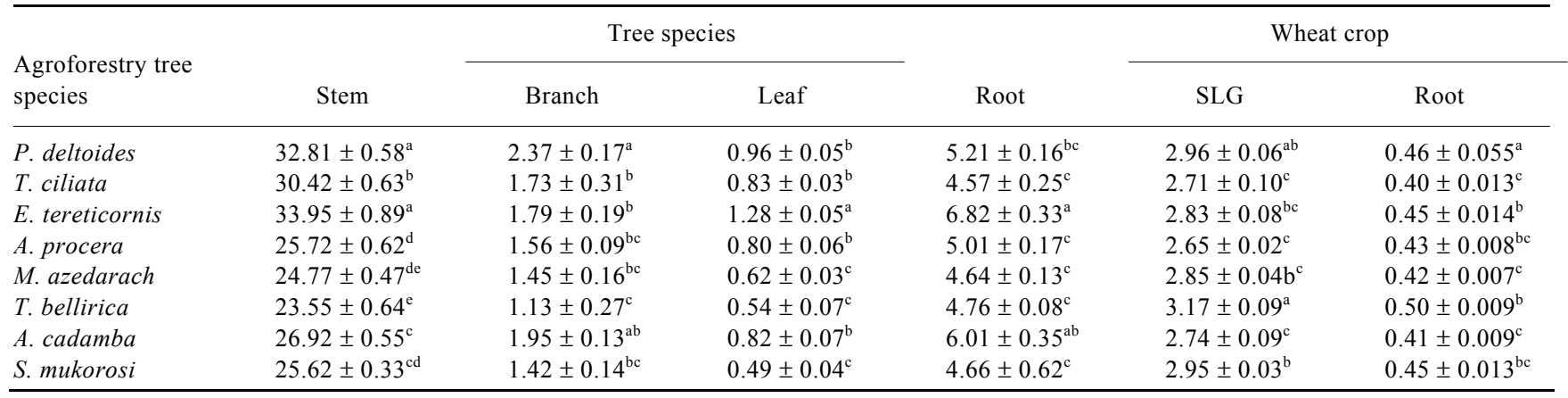

Table 4. Total carbon density $\left(\mathrm{Mg} \mathrm{ha}^{-1}\right)$ under different agroforestry systems

\begin{tabular}{lllc}
\hline $\begin{array}{l}\text { Agroforestry } \\
\text { system }\end{array}$ & Tree species & Wheat crop & Soil \\
\hline P. deltoides & $41.33 \pm 0.49^{\mathrm{b}}$ & $3.59 \pm 0.05^{\mathrm{ab}}$ & $30.75 \pm 2.06^{\mathrm{b}}$ \\
T. ciliata & $37.53 \pm 0.74^{\mathrm{c}}$ & $3.11 \pm 0.09^{\mathrm{e}}$ & $25.93 \pm 0.67^{\mathrm{de}}$ \\
E. tereticornis & $43.85 \pm 0.70^{\mathrm{a}}$ & $3.34 \pm 0.12^{\mathrm{cd}}$ & $37.50 \pm 3.52^{\mathrm{a}}$ \\
A. procera & $33.08 \pm 0.68^{\mathrm{e}}$ & $3.07 \pm 0.03^{\mathrm{e}}$ & $26.56 \pm 0.75^{\mathrm{b}}$ \\
M. azedarach & $31.47 \pm 0.75^{\mathrm{ef}}$ & $3.25 \pm 0.03^{\mathrm{cde}}$ & $28.46 \pm 1.06^{\mathrm{c}}$ \\
T. bellirica & $30.0 \pm 0.51^{\mathrm{f}}$ & $3.65 \pm 0.09^{\mathrm{a}}$ & $26.53 \pm 1.14^{\mathrm{d}}$ \\
A. cadamba & $35.70 \pm 0.53^{\mathrm{d}}$ & $3.14 \pm 0.11^{\mathrm{de}}$ & $24.41 \pm 1.26^{\mathrm{f}}$ \\
S. mukorosi & $32.20 \pm 0.24^{\mathrm{e}}$ & $3.39 \pm 0.02^{\mathrm{bc}}$ & $25.78 \pm 0.75^{\mathrm{de}}$ \\
\hline
\end{tabular}

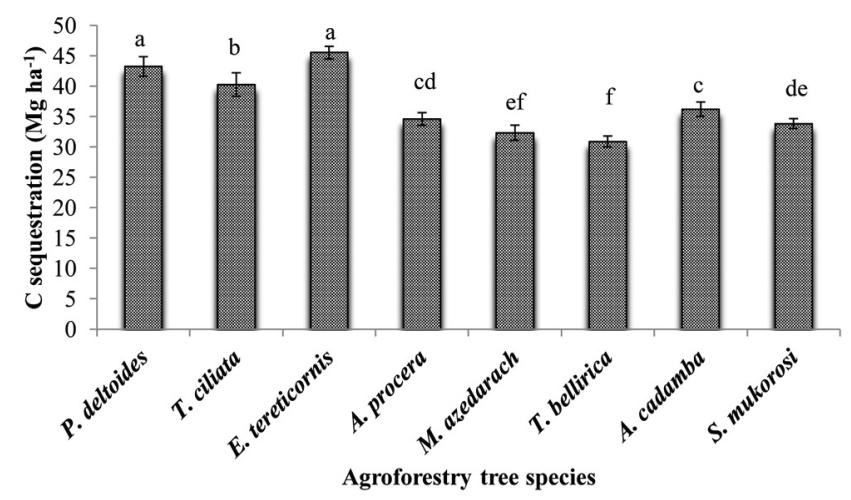

Figure 2. Carbon sequestration through different agroforestry tree species.

the upper soil layer provides access to the moisture and nutrients available in the topsoil. Similarly, in the present study, more organic carbon was reported in the $0-30 \mathrm{~cm}$ soil layer.

Higher wheat biomass was recorded in $P$. deltoids and E. teriticornis-based agroforestry systems. This might be due to higher accumulation of carbon in these agroforestry systems, resulting in better growth of understorey crops. On the other hand, decreasing crop biomass in other agroforestry systems might be due to competition between trees and crops for resource sharing, i.e. light, water and nutrients, resulting in a decrease in the accumulation of dry matter ${ }^{16}$. Considerable amount of carbon is allocated in C. illinoinensis-based agroforestry systems than other agroforestry systems. Biomass differences in various agroforestry systems might be due to a variety of factors, such as growth conditions, site quality, age, density, structure and management practices, and their association with tree species.

Carbon stocks depend on tree density and different components of various species such as stem, branch, leaf, etc. In the present study, carbon content in the stem of the Dalbergia sissoo was higher than its leaves and branches ${ }^{17}$. Studies have also suggested that stem wood biomass accounted for $49.7-51.7 \%$ of the total biomass. The concentration of carbon in biomass is a critical indicator for the determination of carbon sequestration in any plant.

The highest contribution of carbon sequestration was shown by stump roots $>$ lateral roots $>$ fine roots. The long-lived carbon remaining in the tree after its life cycle is resistant to microbial attacks during decomposition due to higher lignin content. Thus, it sequesters carbon for a longer time after felling, compared to the carbon stored in leaf and branch biomass ${ }^{18}$. The stem contributes maximum to total carbon sequestration in all tree species among the sub-components of a tree. The contribution of total carbon stock of different components of the treebased agroforestry system is in the order of tree stem $>$ branch $>$ root $>$ litter ${ }^{19}$.

$\mathrm{CO}_{2}$ mitigation of plants is directly related to biomass of the tree. Maximum biomass production in tree components is responsible for mitigating more $\mathrm{CO}_{2}$ from the atmosphere. In the present study, higher $\mathrm{CO}_{2}$ mitigation was recorded in the E. teriticornis and $P$. deltoids agroforestry systems. This might be due to more biomass and carbon stock accumulation in these agroforestry systems. Previous studies also showed that higher mitigation value of pecan nut + wheat system and pecan nut + lentil system is attributed to more biomass and carbon stock in the agroforestry system compared to sole agriculture system $^{20}$. Various factors such as species, site, age and silvicultural practices may favour tree growth and productivity which promote $\mathrm{CO}_{2}$ sequestration as well as $\mathrm{C}$ conservation. Agroforestry practices in many parts of the 


\section{RESEARCH COMMUNICATIONS}

Himalayan region provide an important environmental service through mitigation of atmospheric $\mathrm{CO}_{2}$ (ref. 21).

Considering the components of different tree species, for long-term storage and coal substitution, carbon sequestration was significantly $(P \leq 0.05)$ higher in the E. teriticornis and $P$. deltoids agroforestry systems. This might be due to higher biomass accumulation in these tree species. In the tree components, stem can sequester carbon for a long time after felling compared to carbon stored in the leaf and branch biomass ${ }^{22}$. However, carbon sequestration potential of above- and below-ground vegetation is highly varied in the agroforestry systems, which has drawn more attention to adaptation and mitigation of climate change $\mathrm{e}^{23}$. It was reported that agroforestry can store carbon in the range $12-228 \mathrm{Mg} \mathrm{ha}^{-1}$, which varies with location, age, density and plantation, as well as the quality of stock planting ${ }^{24}$.

Soil carbon stock was estimated to be higher in E. teriticornis and $P$. deltoids agroforestry systems. This might be due to the fact that soil organic carbon (SOC) sequestration relies primarily on the processes of soil $\mathrm{C}$ input and soil stabilization. Plant root and rhizospheric inputs contribute significantly to $\mathrm{SOC}^{25}$. However, the relation between quality of plant litter and SOC is not yet well understood $^{26}$. Generally, higher SOC pools in agroforestry systems can be achieved by increasing the amount of biomass $\mathrm{C}$ returned to the soil and enhancing soil organic matter ${ }^{27}$. Whereas, the formation and stabilization of SOC might be influenced more by the amount of litter input and its interaction with the soil matrix than the litter qual$i^{28}$. Carbon sequestration in agroforestry systems also improved by increasing the proportion of stabilized SOC fraction in deeper soil horizons ${ }^{29}$. This might be due to the decomposition of dead tree roots, root exudates and associated microorganisms ${ }^{30}$. Functionally important tree species, i.e. those with deep and extensive root systems that increase $\mathrm{C}$ input into the soil, may have a high potential to increase SOC sequestration in agroforestry systems $^{31}$. Broadleaf trees have a more deep-anchored root system, i.e. higher ratios of root biomass/above-ground biomass, and can therefore produce higher SOC inputs from roots ${ }^{32}$.

In the present study, biomass production and carbon stock of vegetation differed in agroforestry systems. All the species used in the study showed great potential for $\mathrm{C}$ sequestration and $\mathrm{CO}_{2}$ mitigation. In tree stem biomass, $\mathrm{C}$ stock and $\mathrm{CO}_{2}$ mitigation were considerably higher compared to root and followed the order: stem $>$ root $>$ branch $>$ leaf. Trees contribute more biomass and consequently store more carbon, but crops in agroforestry still make a major contribution to the production of biomass and carbon stock. Compared to other agroforestry systems, soil carbon density was higher in the E. tereticornis-based agroforestry system due to the addition of more litter to the soil. Therefore, the present study indicates that in this evolving climate change scenario, agroforestry systems are more appropriate for biomass and carbon storage.

1. Albrecht, A. and Kandji, S. T., Carbon sequestration in a tropical agroforestry system. Agric. Ecosyst. Environ., 2003, 99, 15-27.

2. Oelbermann, M., Voroney, R. P. and Gordon, A. M., Carbon sequestration in tropical and temperate agroforestry systems: a review with examples from Costa Rica and southern Canada. Agric. Ecosyst. Environ., 2004, 104, 359-377.

3. Yadav, R. P., Gupta, B., Bhutia, P. L., Bisht, J. K. and Pattanayak, A., Sustainable agroforestry systems and their structural components as livelihood options along an elevation gradient in central Himalaya. Biol. Agric. Hortic., 2018, 1-23; doi:10.1080/ 01448765.2018.1457982.

4. Nair, P. K. R., Kumar, B. M. and Nair, V. D., Agroforestry as a strategy for carbon sequestration. J. Plant Nutr. Soil Sci., 2009, 172, 10-23.

5. Rayment, G. E. and Higginson, F. R., Australian Laboratory Handbook of Soil and Water Chemical Methods, Inkata Press Pty Ltd, 1992.

6. Magnussen, S. and Reed, D., Modeling for estimation and monitoring. national forest assessments - knowledge. Food and Agriculture Organization-International Union of Forest Research Organizations, 2004; http://www.fao.org/forestry/8758/en/

7. Rogelj, J., Meinshausen, M., Schaeffer, M., Knutti, R. and Riahi, $\mathrm{K}$., Impact of short-lived non- $\mathrm{CO}_{2}$ mitigation on carbon budgets for stabilizing global warming. Environ. Res. Lett., 2015, 10, 075001 .

8. Wang, X. and Fenz, Z., Atmospheric carbon sequestration through agroforestry in China. Energy, 1995, 20(2), 117-121.

9. Brown, S., Exploration of the carbon sequestration potential of classified forests in the Republic of Guinea. Report submitted to the United States Agency for International Development, Winrock International, VA, USA, 2003, p. 123.

10. Swamy, S. L. and Puri, S., Biomass production and carbon sequestration of Gmelina arborea in plantation and agroforestry system in India. Agrofor. Syst., 2005, 64, 181-195.

11. Ali, A. and Mattsson, E., Individual tree size inequality enhances aboveground biomass in home garden agroforestry systems in the dry zone of Sri Lanka. Sci. Total Environ., 2017, 575, 6-11.

12. Rizvi, R. H., Dhyani, S. K., Yadav, R. S. and Singh, R., Biomass production and carbon stock of popular agroforestry systems in Yamunanagar and Saharanpur districts of northwestern India. Curr. Sci., 2011, 100, 736-742.

13. Dean, T. J. and Baldwin, V. C., Crown management and stand density. In Growing Trees in a Greener World: Industrial Forestry in the 21st Century: 35th LSU Forestry Symposium (ed. Carter, M. C.), Louisiana State University Agricultural Center, Louisiana Agricultural Experiment Station, Baton Rouge, LA, 1996, pp. 148-159.

14. Goswami, S., Verma, K. S. and Kaushal, R., Biomass and carbon sequestration in different agroforestry systems of a Western Himalayan watershed. Biol. Agric. Hortic., 2013, 30, 88-96.

15. Husmann, K., Rumpf, S. and Nagel, J., Biomass functions and nutrient contents of European beech, oak, sycamore maple and ash and their meaning for the biomass supply chain. J. Clean. Prod., 2018, 172, 4044-4072; https://doi.org/10.1016/j.jclepro.2017. 03.019

16. Devagiri, G. M. et al., Assessment of above-ground biomass and carbon pool in different vegetation types of the southwestern part of Karnataka, India using spectral modeling. Trop. Ecol., 2013, 54, 149-165.

17. Negi, J. D. S., Manhas, R. K. and Chauhan, P. S., Carbon allocation in different components of some tree species of India: a new approach for carbon estimation. Curr. Sci., 2003, 85, 1528-1531. 
18. Ajit et al., Modeling analysis of potential carbon sequestration under existing agroforestry systems in three districts of IndoGangetic plains in India. Agrofor. Syst., 2013, 87, 1129-1146.

19. Thevathasan, N. V. and Gordon, A. M., Poplar leaf biomass distribution and nitrogen dynamics in a poplar-barley intercropped system in southern Ontario, Canada. Agrofor. Syst., 1997, 37(1), 79-90.

20. Yadav, R. P., Bisht, J. K. and Bhatt, J. C., Biomass, carbon stock under different production systems in the mid-hills of Indian Himalaya. Trop. Ecol., 2017, 58(1), 15-21.

21. Wani, N., Velmurugan, A. and Dadhwal, V. K., Assessment of agricultural crop and soil carbon pools in Madhya Pradesh, India. Trop. Ecol., 2010, 51, 11-19.

22. Kaul, M., Mohren, G. M. J. and Dadhwal, V. K., Carbon storage and sequestration potential of selected tree species in India. Mitig. Adapt. Strat. Global Climate Change, 2013, 15, 489-510.

23. Nair, P. K. R. and Garrity, D., Agroforestry research and development: the way forward. In Agroforestry - The Future of Global Land Use (eds Nair, P. K. R. and Garrity, D.), Springer, Dordrecht, The Netherlands, 2012, pp. 515-531.

24. Gera, M., Mohan, G., Bisht, N. S. and Gera, N., Carbon sequestration potential of agroforestry under CDM in Punjab state of India. Indian J. For., 2011, 34, 1-10.

25. Schmidt, M. W. I. et al., Persistence of soil organic matter as an ecosystem property. Nature, 2011, 478, 49-56.

26. Torn, M. S., Swanston, C. W., Castanha, C. and Trumbore, S. E., Storage and turnover of natural organic matter in soil. In Biophysico-Chemical Processes Involving Natural Nonliving Organic Matter in Environmental Systems (eds Senesi, N., Xing, B. and Huang, P. M.), Wiley, Hoboken, NJ, USA, 2009, pp. 219-272.

27. Lal, R., Soil carbon sequestration in natural and managed tropical forest ecosystems. J. Sustain. For., 2005, 21, 1-30.

28. Gentile, R., Vanlauwe, B. and Six, J., Litter quality impacts shortbut not long-term soil carbon dynamics in soil aggregate fractions. Ecol. Appl., 2011, 21, 695-703.

29. Shi, S., Zhang, W., Zhang, P., Yu, Y. and Ding, F., A synthesis of change in deep soil organic carbon stores with afforestation of agricultural soils. For. Ecol. Manage., 2013, 296, 53-63.

30. Lorenz, K. and Lal, R., Carbon Sequestration in Forest Ecosystems, Springer, Dordrecht, The Netherlands, 2010.

31. Kell, D. B., Large-scale sequestration of atmospheric carbon via plant roots in natural and agricultural ecosystems: why and how. Philos. Trans. R. Soc. London, Ser. B., 2012, 367, 1589-1597.

32. Laganière, J., Angers, D. and Paré, D., Carbon accumulation in agricultural soils after afforestation: a meta-analysis. Global Change Biol., 2010, 16, 439-453.

Received 4 October 2020; revised accepted 18 January 2021

\section{BDNF protects photoreceptors from light-induced oxidative stress through upregulating CERKL in vitro}

\author{
Qianwen $\mathrm{He}^{1, \#}$, Juan Yang ${ }^{2, \#}$, Mengting Gao ${ }^{3}$ \\ and Yinxian Wen ${ }^{4, *}$ \\ ${ }^{1}$ Department of Anesthesiology, Zhongnan Hospital of Wuhan \\ University, Wuhan 430071, China \\ ${ }^{2}$ Department of Operations Management, Zhongnan Hospital of \\ Wuhan University, Wuhan 430071, China \\ ${ }^{3}$ Department of Statistics, Renmin Hospital of Wuhan University, \\ Wuhan 430071, China \\ ${ }^{4}$ Department of Orthopedic Surgery, Zhongnan Hospital of \\ Wuhan University, Wuhan 430071, China
}

Brain-derived neurotrophic factor (BDNF) protects the retina from light-induced injury. In this study, white light suppressed the cell viability of $661 \mathrm{~W}$ photoreceptor cells in a time- and intensity-dependent manner, decreased the mRNA and protein levels of ceramide kinase-like (CERKL), but increased the reactive oxygen species (ROS) content in $24 \mathrm{~h}$. Decrease in ROS content and increase in CERKL level were detected after BDNF treatment. BDNF also attenuated the light-induced ROS accumulation, as well as cell viability and CERKL suppression. Thus, strong light causes CERKL suppression, ROS accumulation and the consequent attenuation of photoreceptor viability, while BDNF protects it from such injuries through upregulating CERKL expression and downregulating $R O S$ accumulation.

Keywords: Brain-derived neurotrophic factor, ceramide kinase-like, light-induced injury, photoreceptors, reactive oxygen species.

RETINAL degeneration, such as retinitis pigmentosa and age-related macular degeneration, is a retinopathy typically characterized by pathological loss of highly differentiated cells, especially photoreceptor cells, which may lead to irreversible visual impairment and even blindness ${ }^{1}$. Although the incidence is high and keeps rising, there is currently no effective treatment for retinal degeneration.

A wide variety of causes have been proved to attribute to retinal degeneration, among which retinal light injury is regarded as an important factor. In the retina, prolonged or high-intensity exposure to visible light results in apoptosis of photoreceptor cells, and development of intracellular reactive oxygen species (ROS) and lipid peroxidation ${ }^{2}$. The accumulation of ROS in the photoreceptors is one of the major pathophysiological changes in the light-induced retinal degeneration ${ }^{3-5}$, which further leads to apoptosis of photoreceptor cells and eventually blindness.

*For correspondence. (e-mail: wenyinxian@whu.edu.cn)

${ }^{*}$ Contributed equally to this work. 